Supporting information for

\title{
Reactivity and core-ionization energies in conjugated dienes. Carbon 1s photoelectron spectroscopy of 1,3-pentadiene
}

\author{
T. Darrah Thomas, Leif J. Scethre, Knut J. Børve, Maria Gundersen, and Edwin Kukk
}

Department of Chemistry, Oregon State University, Corvallis, Oregon, USA 97331-4003,

Department of Chemistry, University of Bergen, NO-5007 Bergen, Norway, Department of

Physics, Laboratory of Materials Science, University of Turku, FI-20014 Turku Finland

\section{Full reference for Gaussian}

Gaussian 03, Revision A.1, Frisch,M. J.; Trucks, G. W.; Schlegel, H. B.; Scuseria, G. E.; Robb, M. A.; Cheeseman, J. R.; Montgomery, Jr., J. A.; Vreven, T.; Kudin, K. N.; Burant, J. C.; Millam, J. M.; Iyengar, S. S.; Tomasi, J.; Barone, V.; Mennucci, B.; Cossi, M.; Scalmani, G.; Rega, N. Petersson, G. A. Nakatsuji, H. Hada, M. Ehara, M. Toyota, K. Fukuda, R. Hasegawa, J. Ishida, M.; Nakajima, T.; Honda, Y.; Kitao, O.; Nakai, H.; Klene, M.; Li, X.; Knox, J. E.; Hratchian, H. P.; Cross, J. B.; Adamo, J.; Jaramillo, R.; Gomperts, R. E.; Stratmann, O.; Yazyev, A. J.; Austin, R.; Cammi, C.; Pomelli, C.; Ochterski, J. W.; Ayala, P. Y.; Morokuma, K.; Voth, G. A.; Salvador, P.; Dannenberg, J. J.; Zakrzewski, V. G.; Dapprich, S.; Daniels, A. D.; Strain, M. C.; Farkas, O.; Malick, D. K.; Rabuck, A. D.; Raghavachari, K.; Foresman, J. B.; Ortiz, J. V.; Cui, Q.; Baboul, A. G.; Clifford, S.; Cioslowski, J.; Stefanov, B. B.; Liu, G.; Liashenko, A.; Piskorz, P.; Komaromi, I.; Martin, R. L.; Fox, D. J.; Keith, T.; Al-Laham, M. A.; Peng,C. Y.; Nanayakkara, A.; Challacombe, M.; Gill, P. M. W.; Johnson, B.; Chen, W.; Wong, M. W.; Gonzalez, C.; Pople, J. A. Gaussian, Inc., Pittsburgh PA, 2003.

\section{Calculation of transition states and proton affinities}

We have calculated transition-state energies for the addition of $\mathrm{HCl}$ across the double bonds in ethene, propene, 2-methylpropene, 1,3-butadiene, and 1,3-pentadiene. For these calculations we have augmented the basis sets for $\mathrm{HCl}$ and for the $\mathrm{sp}^{2}$ carbons with additional diffuse functions. The diffuse functions for the $\mathrm{sp}^{2}$ carbon atoms and for hydrogen in $\mathrm{HCl}$ are even-tempered functions determined from the two most diffuse functions given by Dunning: ${ }^{1}$ carbon $(s, p) \alpha \_s=0.04561 ; \alpha \_p=$ 0.03344 , hydrogen (s) $\alpha \_s=0.0709$. For chlorine the triple-zeta basis set $(12 \mathrm{~s}, 9 \mathrm{p}) /[6 \mathrm{~s}, 5 \mathrm{p}]$ of McLean and Chandler ${ }^{2}$ was augmented by diffuse even-tempered functions: $(s, p) \alpha \_s=0.0600 ; \alpha \_p=0.0314$, plus doubly-split polarization functions. The double polarization set was prepared from the original ${ }^{3}$ single $\mathrm{d}$ exponent $\alpha=0.75$ by replacing it by $2 \alpha=1.50$ and $\alpha / 2=0.375$, following a general recipe. ${ }^{4}$

The calculated transition state energies $\left(\Delta \mathrm{E}_{0}^{\#}\right)$ are given relative to the energy of the separated molecules. The zero-point energies have been included. The values are listed in Table 1, where they are compared with available experimental data. ${ }^{5}$ We see that this procedure gives calculated 
transition-state energies that are in near agreement with the experimental values. In detail, the calculated values are about $2 \mathrm{kcal} / \mathrm{mol}$ lower than the experimental values and reproduce within a few percent the variation in activation energy with molecular type.

Also shown in Table 1 are the calculated and experimental proton affinities ${ }^{6}$ as well as the calculated protonation energies.

Table 1. Proton affinities $\left(\Delta \mathrm{H}_{298}\right)$ of olefins and activation energies $\left(\Delta \mathrm{E}_{0}^{\#}\right)$ for addition of $\mathrm{HCl}$ to olefins, $\mathrm{kcal} / \mathrm{mol}$

\begin{tabular}{|c|c|c|c|c|}
\hline \multirow[t]{2}{*}{ Molecule and site of hydrogen addition } & \multicolumn{2}{|c|}{$\begin{array}{c}\text { Activation } \\
\text { energy }\end{array}$} & \multicolumn{2}{|c|}{ Proton affinity } \\
\hline & $\begin{array}{l}\Delta \mathrm{E}_{0}^{\#} \\
\text { calc. }\end{array}$ & $\begin{array}{c}\Delta \mathrm{E}_{0}^{\#} \\
\text { exp. } \\
\text { Ref. } 5\end{array}$ & $\begin{array}{l}\Delta \mathrm{H}_{298} \\
\text { calc. }\end{array}$ & $\begin{array}{c}\Delta \mathrm{H}_{298} \\
\text { exp. } \\
\text { Ref. } 6\end{array}$ \\
\hline ethene & 37.3 & 39.7 & 163.4 & 162.6 \\
\hline propene $\mathrm{C} 1$ & 31.3 & 34.5 & 183.0 & 179.6 \\
\hline propene $\mathrm{C} 2$ & 39.0 & 41.3 & & \\
\hline 2-methylpropene C1 & 26.3 & 28.5 & & \\
\hline 2-methylpropene $\mathrm{C} 2$ & 40.3 & 41.7 & & \\
\hline 1,3-butadiene C1 & 31.1 & & 192.6 & 187.2 \\
\hline 1.3-butadiene $\mathrm{C} 2$ & 41.6 & & & \\
\hline 1,3-pentadiene $\mathrm{C} 1$ & 27.1 & & 205.5 & \\
\hline 1,3-pentadiene $\mathrm{C} 2$ & 41.4 & & & \\
\hline 1,3-pentadiene C3 & 36.8 & & & \\
\hline 1,3-pentadiene C4 & 34.0 & & 190.6 & \\
\hline
\end{tabular}


Table 2. Calculated carbon 1s ionization energies. Relative to C5 in 1,3-pentadiene, eV

\begin{tabular}{lclc}
\hline Molecule & $\Delta \mathrm{I}$ & Molecule & $\Delta \mathrm{I}$ \\
\hline ethane & - & 1,3 -butadiene & -0.609 \\
& 0.040 & $\mathrm{C}$,C4 & \\
ethene & 0.185 & $\begin{array}{l}1,3 \text {-butadiene } \\
\text { C2,C3 }\end{array}$ & 0.173 \\
& & 1,3 -pentadiene C1 & -0.991 \\
propene C1 & - & & \\
& 0.459 & 1,3 -pentadiene C2 & -0.071 \\
propene C2 & 0.088 & 1,3 -pentadiene C3 & -0.334 \\
propene C3 & 0.134 & 1,3 -pentadiene C4 & -0.554 \\
& & 1,3 -pentadiene C5 & 0.000 \\
\hline
\end{tabular}

1. Dunning, Jr.,T. H. J. Chem. Phys., 1971, 55, 716.

2. McLean, A. D.; Chandler, G. S. J. Chem. Phys., 1980, 72, 5639.

3. Francl, M.M.; Petro, W.J.; Hehre, W.J.; Binkley, J.S.; Gordon, M.S.; DeFrees, D.J.; Pople, J.A. J. Chem. Phys. 1982, 77, 3654.

4. Frisch, M.J.; Pople, J.A.; Binkley, J.S. J. Chem. Phys. 1984, 80, 3265.

5. Sæthre, L. J.; Thomas, T. D.; Svensson, S., J. Chem. Soc., Perkin Trans. 2 1997, 749-755.

6. http://webbook.nist.gov/chemistry/ 